\title{
T-lineage blast crisis of chronic myelogenous leukemia: simple record of $\mathbf{4}$ cases
}

\author{
Kartika W. Taroeno-Hariadi ${ }^{*}$, Eiji Tatsumi ${ }^{*}$, Mardiah S.Hardianti ${ }^{*}$, Kaho Furuta ${ }^{*}$, Meilani Syampurnawati ${ }^{*}$, \\ Bambang Karsono $^{\S}$, Takayuki Ishikawa ${ }^{\theta}$, Hiroki Yabe $^{\neq}$, Ken-Ichi Nagai ${ }^{\infty}$, Takayuki Takahashi ${ }^{\ddagger}$, Yuji Kishimoto ${ }^{\ddagger}$
}

\begin{abstract}
Abstrak
Krisis blastik pada lekemia mielositik kronik (CML) bisa berasal dari lini granulosit, monosit, eritrosit, limfoid (sel B atau sel T), dan megakariositik. Krisis blastik seri limfoid biasanya berupa sel B dengan fenotipik sel Pre-B, di mana Ig permukaan belum diekspresikan. Krisis blastik dari sel $T$ sangat jarang didapatkan. Tujuan penelitian : mendeskripsikan gambaran fenotipik, transkrip fusi bcr-abl, dan CD3 sitoplasmik, dan terminal deoxynucleotidyl transferase pada kasus-kasus CML dengan krisis blastik seri limfoid-T. Laporan kasus dari 4 kasus leukemia mielogenik kronik dengan krisis blastik sel-sel T yang dikumpulkan dalam kurun waktu 17 tahun (1987-2004). Kasus-kasus tersebut telah dilakukan pemeriksaan analisis fenotipik dan genotipik pada awal diagnosis ditegakkan. Kesemua kasus menunjukkan adanya t(9;22)(q34;q11). Sampel sel-sel mononuklear pasien yang disimpan dalam bentuk 10\%DMSO diperiksa Reverse Transkripsi (RT) PCR BCR_ABL multiplex untuk mendeteksi transkrip fusi bcr-abl, PCR CD3E untuk mendeteksi Cd3 sitoplasmik, dan PCR TdT untuk mendeteksi terminal deoxynucleotidyl transferase. Hasil analisis antigen permukaan sel pada awal diagnosis menunjukkan 1 kasus CD7+, CD5-, dan CD2-; 1 kasus CD7+, CD5+, dan CD2-; dan 2 kasus CD7+, CD5+, dan CD2+ yang menunjukkan bahwa semua sel T krisis blastik CML berada pada stadium pre dan protimik. Dua kasus menunjukkan hasil positip untuk transkrip bcr-abl b2a2, 1 kasus positip pada ela2, dan 1 kasus negatip. RT PCR CD3E menunjukkan hasil positip pada semua kasus dan RT PCR TdT hanya positip pada 1 kasus. Hasil yang dikumpulkan diharapkan dapat menjadi dasar analisis lebih lanjut pada kasus CML dengan krisis blastik sel-sel T. (Med J Indones 2005; 14: 184-9)
\end{abstract}

\begin{abstract}
Abstrak
Blast crisis (BC) transformation in chronic myelogenous leukemia (CML) can involve each differentiation lineage of the hematopoietic system, i.e. granulocyte, monocyte, erythrocyte, megakaryocyte, and lymphocyte lineage. The lymphoid blast crisis (BC) leukemia cells usually belong to B-lineage, commonly having the phenotype of Pre-B stage of the B-lineage, in which cell-surface immunoglobulin(sIg) is not yet expressed. In contrast, T-lineage BC of CML is extremely rare. The objective of this study is to describe the fenotype, fusion transcript of bcr-abl, TdT, and cytoplasmic CD3 in T-lineage BC CML cases. Case report study. This report shows a simple summary of 4 cases of T-lineage BC of CML which have been collected in the phenotypic and genotypic analysis study for 17 years (1987-2004). In all cases, the chromosomal analysis revealed the presence of $t(9 ; 22)(q 34 ; q 11)$ at presentation. Cell surface analysis were done at diagnosis. Cases' mononuclear cells stored as 10\% DMSO were retrieved to be performed reverse transcription (RT) PCR BCR-ABL multiplex to demonstrate the presence of the fusion transcript of bcr-abl. RT-PCR was also performed for detecting the expression of cytoplasmic $C D 3 \varepsilon$ and terminal deoxynucleotydil transferase (TdT). The results of cell surface antigen (CSA) at presentation showed that 1 case was $C D 7+, C D 5-$, and CD2-; 1 case CD7+, CD5+, and CD2-; and 2 cases CD7+, CD5+ and CD2+ indicating that all these T-lineage BC of CML cells show the phenotype of pre-(pro-) thymic stage phenotype. In the present study, two cases showed b2a2, one ela2, and one negative bcr-abl transcript. The RT-PCR revealed the presence of CD3E $m R N A$ in all cases, and TdT $m R N A$ in only one case. These results can constitute a basis for the future analysis of T-lineage BC of CML from now on. (Med J Indones 2005; 14: 184-9)
\end{abstract}

Keywords: Chronic Myelogenous Leukemia (CML), Blastic Crisis (BC), T-lineage, bcr-abl fusion gene, CD3E, TdT

\footnotetext{
* International Center for Medical Research and Treatment, Kobe University School of Medicine, Kobe, Japan

${ }^{f}$ Divisi Hematology and Medical Oncology, Department of Internal Medicine, Dr. Sardjito Hospital / Faculty of Medicine, Gadjah Mada University, Jogjakarta, Indonesia

${ }^{\S}$ Divisi Hematology and Medical Oncology, Department of Internal Medicine, Cipto Mangunkusumo Hospital / Faculty of Medicine, University of Indonesia, Jakarta, Indonesia

${ }^{\theta}$ Kobe City General Hospital, Kobe Japan

${ }^{7}$ Kobe University Hospital, Kobe, Japan

${ }^{\infty}$ Mitsubishi Kobe Hospital, Kobe, Japan

${ }^{*}$ Kansai Medical University Hospital, Kobe, Japan
}

Chronic Granulocytic Leukemia (CGL) is a well defined myeloproliferative disorder associated in more than $90 \%$ of cases with the Philadelphia chromosome (Ph). ${ }^{1}$ CGL originates from multipotent hematopoietic stem cell. Progeny of this transformed cell include granulocytic, erythroid, megakaryocytic, monocytic cells, eosinophils, and lymphocytes. ${ }^{2}$ CGL initially present with indolent or chronic phase course, easily controlled with therapy. After a variable period of time, usually 2-4 years, patients will enter into an 
accelerated phase and result in a terminal phase, referred to as blast crisis (blast transformation, BC). ${ }^{3}$ Blast crisis is characterized by the appearance of at least $20 \%$ blast cells in the peripheral blood and bone marrow nucleated cells, and extra medullary blast proliferation, or aggregation of blast in bone marrow biopsy specimen with localized immature blast and refracter splenomegaly. ${ }^{4,5}$ The blast crisis cells from majority of patients are thought to resemble acute myeloblastic leukemia, and one-third of patients' blasts morphologically resemble the blasts of acute lymphoblastic leukemia (ALL). ${ }^{1,6}$ The blast in this lymphoid BC commonly show L1 or L2 (FAB morphology), have positive terminal deoxynucleotydil transferase (TdT) results, and pre-B cell immunophenotypic profile (CD19+, CD20- or low +, CD10+, cytoplasmic Ig \pm , surface Ig-). ${ }^{7}$ In contrast, CML-BC of T-lineage has been only very rarely reported. CML-BC of erythroid or megakaryocyte lineage or CML-BC with very undifferentiated feature showing no lineage marker, has also been reported only very rarely. ${ }^{6}$ Here, we showed a simple summary of 4 cases of T-lineage CML-BC.

\section{METHODS}

Four samples from T-lineage CML-BC CGL had been collected from 1987 to 2004. Diagnoses of blast crisis was determined according to WHO criteria, morphological features, cytochemistry, and cell-surface antigen analysis. In all cases, the chromosomal analysis revealed the presence of $\mathrm{t}(9 ; 22)(\mathrm{q} 34 ; \mathrm{q} 11)$ at presentation.

Bone marrow or peripheral bloods were collected into preservative-free heparin, and erythrocytes are removed by density gradient sedimentation in Ficoll-Hypaque. Interface cells were washed twice in PBS and added with RPMI 1640 containing 10\% FCS. $^{8}$

\section{Cell surface antigen analysis}

Cell-surface antigen analysis were detected at presentation by direct and indirect cell-surface immunofluorescence with a total of 20 monoclonal antibodies to identify antigen of T-cell, B-cell, myeloid cell, precursor cells, monocyte, and megakaryoblastic cell: NUIa (HLADR), NUTer (CD2), NUTpan (CD5), Leu4 (CD3), NUTH/1 (CD4), NUT-S/C (CD8), NU-B2 (CD20), NUN1 (CD10), MCS2 (CD13), were purchased from Nichirei Tokyo, Japan), BA-1 (CD24) was from Boehringer Manheim (Manheim, Germany); Leu9 (CD7),
Leu12 (CD19), Leu-M1(CD15), were from BectonDickinson (Mountain View, CA); Mo1(CD11b), My4 (CD14), My9 (CD33), were from Coulter (Hialeah, FL), OKT10 (CD38) was from Fujisawa, OKM5 (CD36) was from Ortho-mune, HIP 8 (CD 41a), HIP1 (CD42), were from Becton Dickinson.

One hundred micro liter of RPMI 1640 (Nissui, Tokyo, Japan) containing $4 \times 10^{5}$ cells was incubated with appropriately diluted conjugated or unconjugated monoclonal antibodies. Fluorescence isothyocyanate (FITC)-conjugated F(ab')2 antimouse $\mathrm{IgG}$ was used for indirect immunofluorescence. Heat aggregated human IgG $(50 \mathrm{mg} / \mathrm{ml})($ Venilon; Fujisawa, Osaka, Japan) was added ten minutes before each incubation to block Fc receptor. Incubation was performed for 30 minutes at $4^{\circ} \mathrm{C}$. The stained cells were assayed with an EPICS-C flowcytometer (Coulter). ${ }^{8}$

\section{Terminal Deoxynucleotidyl Transferase Reverse Transcription Polymerase Chain Reaction assay (TdT RT-PCR)}

Complimentary DNA (cDNA) was synthesized using random primer (TaKara kypp, japan) and M-MLV reverse transcriptase (GibcoBRL,NY,USA) from $2 \mu \mathrm{g}$ of sample derived RNA extracted by Trizol (Invitrogen, Carsbald, CA, USA) as previously prepared. ${ }^{9}$ Terminal Deoxynucleotidyl Transferase (TdT) was determined by Reverse TrancriptionPolymerase Chain Reaction(RT-PCR assay using primer TdT1 5'ATG ATA CCC TTC ACC TTG GAC 3' (bp211-221) and TdT 2 5'GTC ACC CAC ATT GTA GCA GAG3' (bp 623-625). PCR was carried out by using Gene $\mathrm{Amp}^{\mathrm{TM}}$ DNA amplification Reagent Kit with Ampli Taq ${ }^{\mathrm{TM}}$ (Takara Shuzo, Kyoto, Japan). TdT RT-PCR was performed with a DNA thermal cycler (Takara Shuzo). After $5 \mathrm{~min}$ at $95^{\circ} \mathrm{C}$, a 30 cycles PCR was performed under the following conditions: a denaturation step at $95^{\circ} \mathrm{C}$ for $60 \mathrm{~s}$, an annealing step at $65^{\circ} \mathrm{C}$ for $60 \mathrm{~s}$, and extension steps at $72^{\circ} \mathrm{C}$ for $2 \min (10 \mathrm{~min}$ in the last cycle).

\section{CD3e RT-PCR assay}

CD3 was identified with monoclonal antibody by flowcytometry or by RT PCR CD3e. RT-PCR CD3 were performed using primer 5' GTC TCC ATC TCT GGA ACC ACA G3' (bp 166-187) and 5'GGC CTT TCT ATT CTT GCT CCA C 3' (bp 504-525) under the following condition: after $5 \mathrm{~min}$ at $94^{\circ} \mathrm{C}$, a 30 cycles of PCR was performed under the following 
conditions; a denaturation step at $94^{\circ} \mathrm{C}$ for 60 s, an annealing steps at $63^{\circ} \mathrm{C}$ for 60 s, and an extension step at $72^{\circ} \mathrm{C}$ for $1 \mathrm{~min}\left(8 \mathrm{~min}\right.$ in the last cycle).$^{10}$

\section{BCR-ABL multiplex PCR}

BCR-ABL fusion gene were determined with BCRABL multiplex PCR, using 4 primer BCR-C 5' ACC GCA TGT TCC GGG ACA AAA G3', B2B 5' ACA GAA TTC GCT GAC CAT CAA TAA G3', C5e5'ATA GGA TCC TTT GCA ACC GGG TCT GAA3', CA3- 5'TGT TGA CTG GCG TGA TGT AGT TGC TTG G3' as previously described. ${ }^{11}$

All the amplified PCR product $(5 \mu \mathrm{l})$ were electrophoresed in $2 \%$ agarose gel stained with ethidium bromide and observed under the UV light transluminator.

\section{RESULT}

There were 4 patients of T-lineage CML-BC (Table 1). All of them were negative for CD4, CD8, CD3, CD10, CD19, CD20, CD14, and CD15. The results of cell surface antigen (CSA) at presentation showed that 1 case was $\mathrm{CD} 7+, \mathrm{CD} 5-$, and $\mathrm{CD} 2-; 1$ case $\mathrm{CD} 7+$, $\mathrm{CD} 5+$, and $\mathrm{CD} 2-$; and 2 cases $\mathrm{CD} 7+, \mathrm{CD} 5+$ and $\mathrm{CD} 2+$ indicating the phenotype of pre-(pro-) thymic stage phenotype.

Expression of CD38 in T-lineage blast crisis were seen in all tested patient. CD13 expression were positive in all $\mathrm{CD} 7+\mathrm{CD} 5+\mathrm{CD} 2-/ \mathrm{CD} 7+\mathrm{CD} 5-\mathrm{CD} 2-$ and in $50 \%$ of $\mathrm{CD} 7+\mathrm{CD} 5+\mathrm{CD} 2+$. CD 33 were expressed in 2 patients; one with CD7+CD5-CD2-, one with $\mathrm{CD} 7+\mathrm{CD} 5+\mathrm{CD} 2+$. HLA-DR was positive in 3 patients, and CD11b were positives in all patients.

Table 1.Sample characteristics and immunophenotyping results of Blast Crisis Chronic Granulocytic Leukemia Patients

\begin{tabular}{|c|c|c|c|c|c|}
\hline & Pt 1 & Pt 2 & Pt 3 & Pt 4 & \\
\hline Diagnosis & T-lineage blast crisis & T-lineage Blast crisis & T-lineage blast crisis & T-lineage & blast crisis \\
\hline Age & 65 & 20 & 65 & 72 & \\
\hline Sex & $\mathrm{M}$ & M & M & M & \\
\hline Date of sample exm & $16-4-1990$ & 13-11-1987 & $2-10-1987$ & $26-7-1995$ & \\
\hline Sample source & PB & $\mathrm{PB}$ & PB & PB & LN \\
\hline \multicolumn{6}{|l|}{ Immunophenotyping $^{a}$} \\
\hline HLA-DR $\dagger$ & + & - & \pm & - & + \\
\hline $\mathrm{TdT}^{*}$ & - & _- & + & - & NT \\
\hline $\mathrm{CD} 38 \dagger$ & + & + & ++ & NT & NT \\
\hline $\mathrm{CD} 7 \dagger$ & ++ & ++ & ++ & - & ++ \\
\hline $\mathrm{CD} 5 \dagger$ & ++ & ++ & ++ & - & - \\
\hline $\mathrm{CD} 2 \uparrow$ & - & ++ & ++ & - & NT \\
\hline $\mathrm{CD} 3 \uparrow$ & - & - & - & - & - \\
\hline CD $3 \varepsilon$ RT PCR* & + & + & + & + & NT \\
\hline $\mathrm{CD} 13 \dagger$ & ++ & ++ & - & ++ & + \\
\hline $\mathrm{CD} 33 \dagger$ & - & + & - & \pm & + \\
\hline $\mathrm{CD} 11 \mathrm{~b}$ & ++ & ++ & ++ & NT & + \\
\hline $\mathrm{CD} 36 \dagger$ & \pm & \pm & NT & NT & NT \\
\hline $\mathrm{CD} 41 \dagger$ & - & \pm & - & NT & NT \\
\hline $\mathrm{CD} 42 \dagger$ & - & - & NT & NT & NT \\
\hline
\end{tabular}

$†$ Antigen expression determined in an indirect immunofluorescence assaay (-) 0-15\% fluorescent cells ( \pm ) 16-25\% (+) 26-40\% (++) 41-100\% NT: not tested

*Antigen expression determined by RT-PCR in 2004

CD4,CD8, CD19, CD20, CD10, CD14,CD15 were always negative 
Surface marker CD3 were always negatives in all tested patients, but CD3 $\varepsilon$ RT PCR revealed a positive expression in all tested patients.

TdT was positive in only one patient. TdT RT- PCR result were shown in Figure.2

Table 2. BCR-abl Multiplex RT-PCR result

\begin{tabular}{lcccc}
\hline & Pt 1 & Pt2 & Pt 3 & Pt 4 \\
\hline e1a2 (481bp) & - & - & - & + \\
b3a2 (385bp) & - & - & - & - \\
b2a2 (310bp) & + & - & + & - \\
BCR (808 bp) & + & + & + & + \\
\hline
\end{tabular}

Two patients were positive for BCR-ABL fusion gene b2a2 transcripts, one patient was positive for e1a2 transcript, and one was negative for BCR-ABL fusion gene (Table 2). Gel electrophoresis for RT-PCR BCRABL result is presented in Figure 3.

\section{DISCUSSION}

Blast transformation eventually develop in both $\mathrm{Ph}$ positive or negative CGL patients. ${ }^{12}$ Blast transformation in CGL is characterized by cell line heterogeneity so that it can be myeloid, lymphoid, megakaryocyte, or erythroid crisis. ${ }^{13}$ It reveals that transformation derived from pluripotential haematopoetic stem cell and also that the blast cell population has capacity to differentiate along several pathway. ${ }^{13}$

The phenotypic feature of CML usually positive for mature myeloid marker, and the phenotype will change according to the cell line transformation.

The incidence of T-lineage blast crisis is low. ${ }^{14}$ There were few cases found and but none of T-cell phenotype had been interpreted, although $\mathrm{T}$ cell antigen were presented 5-30\% of all cases of blast crisis. ${ }^{13,14,15} \mathrm{~T}$ cell-lineage blast crisis usually expresses surface marker resembles to T-ALL which is TdT+, CD10-, HLA DR-, CD7+ (all T cell marker positive can be present), and positive TCR gene arrangement. ${ }^{14}$
Rodriquez-Pinilla et al previously reported a chronic myelogenous leukemia with early progression to extramedullary T-lymphoblastic crisis $(\mathrm{TdT}+\mathrm{CD} 3+$ CD34+ CD43+, PCR p210 for BCR ABL+, and clonal rearrangement of TCRY. ${ }^{15}$

In our cases, all B-cell phenotype marker was negative, and T-cell phenotype showed pre-thymic stage. CD13 positiveness in our cases related to the immaturity of $\mathrm{T}$ cell. $^{16,17} \mathrm{CD} 33$ was positive in 2 cases. CD11b was positive in all patients. Previous study reported that CD11b was not expressed in CD7+CD5-CD2-, but expressed in all CD7+CD5+CD2- T-ALL/LBL. ${ }^{17}$

Usually $\mathrm{TdT}$ is dominantly expressed in most immature hematopoetic cell stage, eg in pro T-cell / pro B-cell stage of maturation, ${ }^{18,19}$ but some previous studies reported that in thymic stage (CD3-CD4-CD8, CD3-CD4+CD8+, CD3+CD4 \pm CD8 \pm lymphoblast) TdT was still almost always expressed. ${ }^{16,17,20}$ Negative TdTs are more easily found in CD7+CD5CD2-lymphoblast. ${ }^{16,17,20}$ Our negative TdT cases might be from positive myeloid marker expressingblasts and the only one positive TdT case was negative myeloid marker expressing-blast. More samples are needed to get the similar conclusion as previously reported that TdT transcripts in myeloid marker + ALL is reduced than in myeloid marker - ALL. ${ }^{19}$

PCR CD3 $\varepsilon$ is done to detect the expression of cytoplasmic $\mathrm{CD} 3$ transcript. $\mathrm{CD} 3 \varepsilon$ transcript was positive, while $\mathrm{CD} 3$ was still negative means that the CD3 $\varepsilon$ molecule has been detected in cytoplasma but the CD3 molecule has not been synthesized and expressed in surface membrane. ${ }^{18}$

The $\mathrm{Ph}$ negative blast crisis, like our case, is also unclear in incidence. ${ }^{12}$ Previously reported $\mathrm{Ph}$ negative blast crisis showed more mature/thymic stage, HLA- DR negative, and TdT negative. ${ }^{12}$ It is thought that $\mathrm{Ph}$ - negative CGL clone evolved to $\mathrm{T}$ cell malignancy, therefore it occurs in a pluripotent stem cell, similar to the situation observed with $\mathrm{Ph}$-positive CGL. The stem cell then differentiates towards the Tlineage and transform there. ${ }^{12}$ 


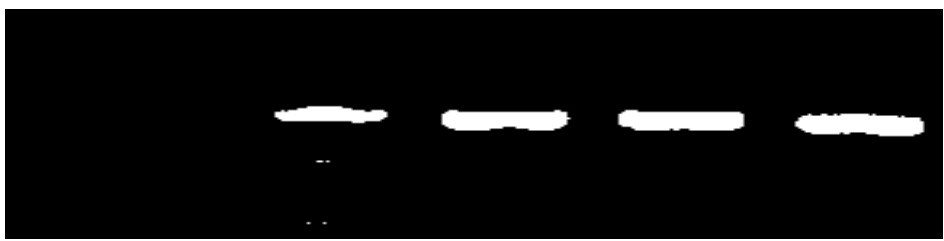

$\beta$ actin $500 \mathrm{bp}$

Figure 1. PCR B-actin 500 bp on 4 patients T-lineage BC CML
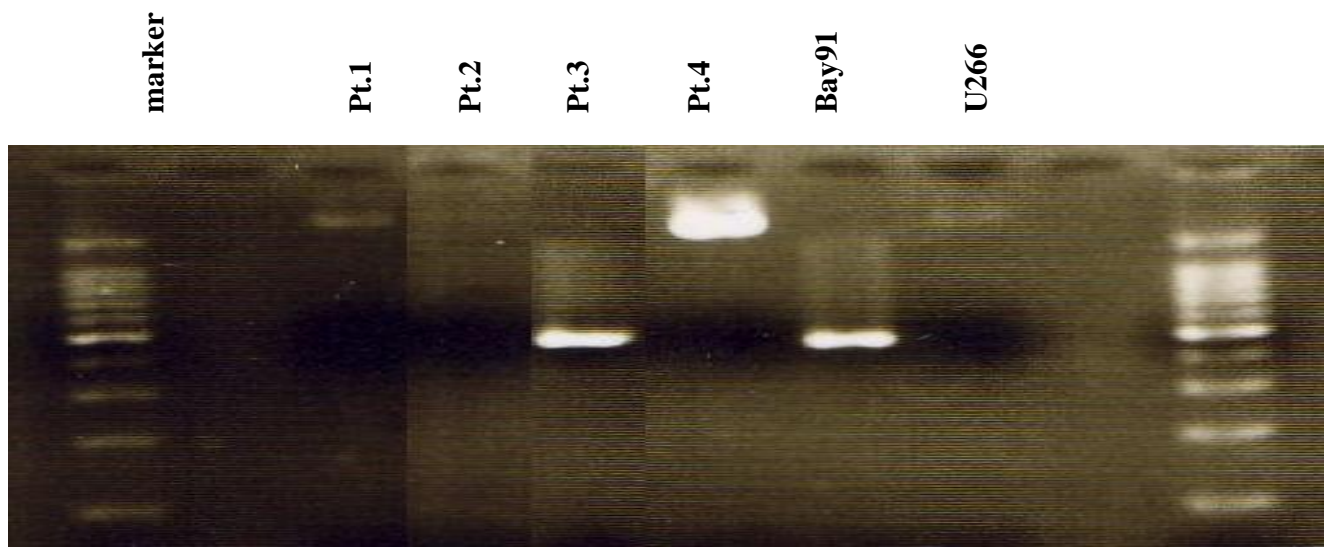

TdT 443 bp
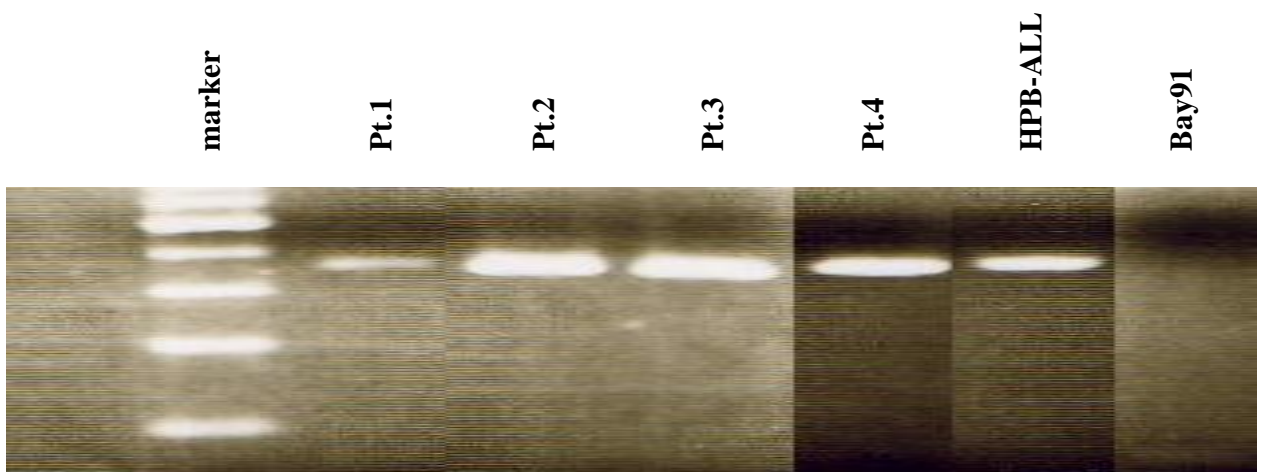

CD3E 360 bp

Figure 2. Expression of TdT and CD3E. Bay91 was used as positive control, and U266 as negative control for TdT.HPB ALL was used for positive control and Bay91 as negative control for CD3E. The marker was 100 bp ladder, the brightest one was $500 \mathrm{bp}$ 


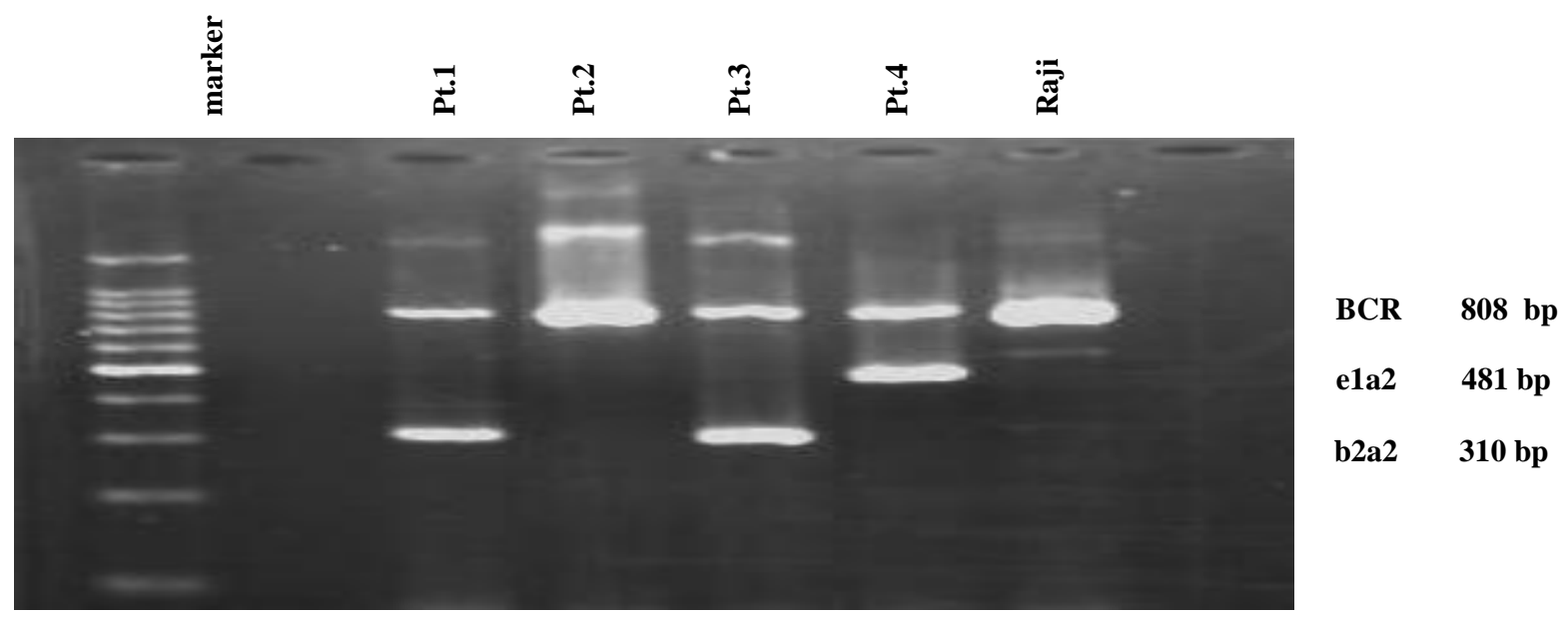

Figure 3. Expression of BCR ABL transcripts. Raji was used as negative control. All BCR band were positive indicated that cDNA quality is good enough. Pt 4 showed negative result for BCR-ABL trancripts.

\section{REFERENCES}

1. Griffin JD, Todd III RF, Ritz J, Nadler LM, Canellos GP, Rosenthal D. Differentiation Patterns in the Blastic Phase of Chronic Myeloid Leukemia. Blood 1983; 61(1):85-91.

2. Turgeoo ML. Clinical Hematology Theory and Procedures $3^{\text {rd }}$ ed. Philadelphia: Lippincott Williams \& Wilkins, 1999.

3. Kantarjian HM, Deisseroth A, Kurzrock R, Estrov Z, Talpaz M. Chronic Myelogenous Leukemia: A Concise Update. Blood 1993; 82(3):691-703.

4. Vardiman JW, Pierre R, Thiele J, Imbert M, Brunning RD, Flandrin F. Chronic Myelogenous Leukemia. In: Jaffe ES, Harris NL, Stein H, Vardiman JW, editors. World Health Organization Classification of Tumours: Pathology and Genetics Tumours of Haematopoietic and Lymphoid Tissues..Lyon: IARC, 2001

5. Bain BJ. Leukaemia Diagnosis. $3^{\text {rd }}$ edition. Massachusetts: Blackwell Publishing, 2003.

6. Griffin JD, Tantravahi, R, Canellos GP, Wisch JS, Reinherz EL, Sherwood G etal. T-cell Surface Antigen in a Patient with Blast Crisis of Chronic Myeloid Leukemia. Blood 1983; 61(4):640-3.

7. Dorfman DM, Longtine JA, Fox EA, Weinberg DS, Pinkus GS. T-Cell Blast Crisis in Chronic Myelogenous Leukemia: Immunophenotypic and Molecular Biologic Findings. ACJP 1997; 107(2)168-175.

8. Kawano S, Tatsumi E, Yoneda N, Yamaguchi N. Pattern of Expression of CD45 RA/RO Isoformic Antigens in Acute myeloblastic Leukemia Cells. AJCP 1993; 100(4): 386-93.

9. Sasaki R, Fukushima M, Miura Y, Chang LMS, Bollum FJ.Sensitivity and Applicability of Different Methods for Detection of Terminal Transferase in Leukemia. Leukemia 1996;10: 1377-82.

10. Bruno L, Res P, Dessing M, Cella M, Spits H. Identification of a Commited T-cell precursor Population in Adult Human Peripheral Blood. J Exp Med. 1997; 185(5): 875-84.

11. Cross, NCP, Melo JV, Feng L, Goldman JM. An Optimized Multiplex Polymerase Chain Reaction (PCR) for Detection of BCR-ABL Fusion mRNAs in Haematological Disorders. Leukemia 1994; 8(1): 186-9.

12. Soda H, Kuriyama K, Tomonaga M, Yao E, Amenomori T, Yoshida Y et al. Lymphoid Crisis with T-cell Phenotypes in a Patient with Philadelphia Chromosome negative Chronic Myeloid Leukaemia. Brit J Haematol, 1995; 59: 671-9.

13. Bettelheim P, Lutz D, Majdic O, Paietta E, Haas O, Linkesch W et al. Cell Lineage Heterogeneity in Blast Crisis of Chronic Myeloid Leukaemia. Brit J Haematol, 1985; 59: 395-409.

14. Sun T. Flow Cytometric Analaysis of Hematologic Neoplasma. New York: Igaku-Shoin, 1993.

15. Rodriguez-Pinilla SM, Gonzales M, Sanchez PM. Systemic Lymphadenopathy in a Patient with Chronic Myelogenous Leukemia. Arch Pathol lab Med. 2003; 127: 249-50.

16. Yoneda N, Tatsumi E, Kawano S, Matsuo Y, Minowada J, Yamaguchi N. Human Recombination Activating Gene1 in leukemia/Lymphoma cells: Expression Depends on stage of Lymphoid Differentiation Defined by Phenotype and Genotype. Blood 1993; 82(1): 207-16.

17. Yoneda N, Tatsumi E, Teshigawara K, Nagata S, Nagano $\mathrm{T}$, Kishimoto $\mathrm{Y}$ et al. lineage Determination of CD7+ CD5- CD2- and CD7+ CD5= CD2- lymphoblasts: Studies on Phenotype, Genotype, and Gene Expression of Myeloperoxidase, $\mathrm{CD} 3 \varepsilon$, and $\mathrm{CD} 3 \delta$

18. Abbas AK, Lichtman AH, Pober JS. Cellular and Molecular Immunology. 4rd edition. Philadelphia: WB saunders Company, 2000

19. Paietta E, Racevskis J,Bennett JM, Wiernik PH. Differential Expression of terminal Transferase (TdT) Acute Lymphocytic Leukaemia Expressing Myeloid Antigens and TdT positive Acute Myeloid Leukaemia as compared to Myeloid Antigen Negative Acute Lymphocytic Leukaemia. Brit J Haematol 1993; 84: 416-22.

20. Tatsumi E, Yoneda N, Kaano S, Yamaguchi N. CD21 Antigen in T-lineage Neoplastic Lymphoid Cells: Characteristic Expression at Thymic Stage. Am J Hematol 1994; 45: 150-5. 
